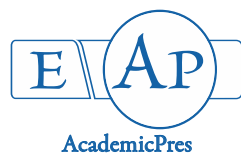

\title{
Microbial Diversity in Water and Biofilm Samples from Well Sources in Ilorin Metropolis, Nigeria
}

\author{
Toyin Olayemi AGBABIAKA ${ }^{1 *}$, Blessing Olubunmi OLOFINTOYE ${ }^{2}$ \\ ${ }^{1}$ University of Ilorin, Department of Microbiology, Ilorin, Nigeria; agbabiaka.to@unilorin.edu.ng ( ${ }^{*}$ corresponding author) \\ ${ }^{2}$ University of Ilorin, Department of Microbiology, Ilorin, Nigeria; olofintoyeblessing@gmail.com
}

\begin{abstract}
The aim of the study was to investigate the microbial populations of water and biofilm samples from seven hand dug wells in Ilorin, Nigeria, which are for private and public use. Physicochemical parameters such as $\mathrm{pH}$, turbidity, total dissolved solids, temperature, conductivity, dissolved oxygen and biological oxygen demand were determined. Biofilm growths were induced from water samples obtained from selected wells. Twenty bacteria isolated were identified using morphological and biochemical characteristics as well as molecular methods and includes Shigella sonnei, Shigella dysenteriae, Micrococcus luteus, Bacillus sphaericus, Salmonella enteritidis, Proteus mirabilis strain IK-MB4-518F, Bacillus licheniformis strain RH104, Bacillus subtilis, Erwinia sp., Proteus vulgaris, Yersina sp., Bacillus cereus, Staphylococcus aureus, Serratia marcescens, Pseudomonas aeruginosa strain GS1, Pseudomonas aeruginosa strain 218B, Staphylococcus epidermidis, Vibrio sp., Escherichia coli and Bacillus pasteurii. Total bacterial count ranged from $1.8 \times 104-1.53 \times 106 \mathrm{cfu} / \mathrm{ml}$. Water samples from these wells are therefore not potable and some of the isolates are potential health hazards to human population.
\end{abstract}

Keywords: biofilm; physicochemical; population; water samples; wells

As access to potable water is limited, hence individuals and communities resort to other less expensive means of obtaining adequate water by their own standards to meet their daily needs. The most common means especially in Nigeria are wide-diameter tube wells.

One of the important sources of well contamination are leachate from various sources considering the rate of population growth, extents of community development and methods of waste managements found around these wells. Researches on landfill leachates have proved the presence of large numbers of pathogenic and opportunistic bacteria, many species belonging to genera such as Enterobacter, Escherichia, Klebsiella, Salmonella, Serratia, Proteus, Pseudomonas and Staphylococcus (Holt et al., 2000; Adeyemi et al., 2007; Flores-Tena et al., 2007), which find their way into surrounding underground waters and ruin their quality (Fatta $e t$ al., 1999). This was further explained by Oshode $e t$ al., (2008), who confirmed the presence of these organisms which are not only pathogenic and opportunistic but also capable of toxin production which increases the virulence potential of such organisms. Efuntoye et al. (2011), showed that some of these organisms exhibit antimicrobial resistance to certain antibiotics.

There is therefore a need to examine dug-wells on a case by case basis in order to determine their potential to be hazardous to human and animal health. 


\section{Materials and Methods}

Sampling areas

Samples were obtained from well 1 (Tanke Bubu), well 2 (Tanke Ajanaku), well 3 (Tanke Ajanaku), well 4 (Tanke Bubu), well 5 (Akerebiata), well 6 (Ipata) and well 7 (Oja Oba) communities within Ilorin metropolis, Kwara State, Nigeria. Three of these wells were private and four were major public wells selected based on population density, nature of the area, absence of and/or unreliable sources of adequate public drinking water distribution systems (DWDS), frequent use of such wells.

\section{Collection of water and biofilm samples}

Water samples were collected from the wells in sterile sample bottles using the water fetcher, screwed properly and transferred to the laboratory in coolers.

Two periodic biofilm samples from the $3^{\text {rd }}$ and $10^{\text {th }}$ day after immersion were taken from each of these wells similar to the work done by Huang et al. (2009). Two filter membranes were withdrawn aseptically on the $3^{\text {rd }}$ and $10^{\text {th }}$ day after the setup had been immersed for analysis in the laboratory.

\section{Physicochemical analysis of water samples}

The physicochemical parameters measured were $\mathrm{pH}$, turbidity, temperature, conductivity, dissolved oxygen and biological oxygen demand.

\section{$p H$}

Potable digital $\mathrm{pH}$ meter was standardized with buffer of $\mathrm{pH} 4,7$ and 9 before being used. The glass electrode was rinsed with distilled water before it was dipped into the samples. The $\mathrm{pH}$ was then read when digital reading stabilized (Kanase et al., 2016).

\section{Turbidity}

Turbidity of the water samples was determined using a $\mathrm{HACH} 2100 \mathrm{~N}$ Turbidimeter. A clean sample bottle of turbidimeter was filled with $25 \mathrm{ml}$ of each sample, covered with light shield and turbidity read in Nephelometric turbidity units (NTU) (Kanase et al., 2016).

\section{Total dissolved solids}

The total dissolved solids (TDS) of water samples was measured with a TDS meter in parts per million (ppm) (Kanase et al., 2016).

\section{Temperature}

Temperature was determined using a mercury-bulb thermometer dipped into each water sample and left for about 5-10 minutes and the thermometer read and recorded in ${ }^{\circ} \mathrm{C}$ (Kanase et al., 2016).

\section{Conductivity}

The conductivity of water samples was measured with a conductivity meter calibrated in $\mathrm{ms} / \mathrm{cm}$ (Kanase et al., 2016).
Dissolved oxygen

Determination of dissolved oxygen was achieved using Winkler titration method. Each water sample from the sampling points was halved. One of the halved samples was placed in the dark (for BOD analysis). The first halved sample was now taken and $2 \mathrm{ml}$ manganese chloride $(\mathrm{aq})(4 \mathrm{~g}$ $\mathrm{MnCl}_{2}$ dissolved in $10 \mathrm{ml}$ distilled water) added to the sample which was followed with the addition of $2 \mathrm{ml}$ alkaline iodide solution $(3.3 \mathrm{~g} \mathrm{NaOH}=2 \mathrm{~g}$ KI dissolved in $10 \mathrm{ml}$ distilled water). The sample was then shaken. Two $\mathrm{ml}$ of concentrated hydrochloric acid was added and shaken. Iodine formed is directly proportional to the dissolved oxygen. Fifty $\mathrm{ml}$ of the above solution was titrated with $0.0125 \mathrm{M}$ sodium trioxosulphate (II) solution using starch as indicator. The end-point was reached when the blueblack colour disappeared. The samples were collected under water to ensure there were no trapped air bubbles.

DO in $\mathrm{mg} / \mathrm{l}=$ Titre value $\times$ Molarity of $\mathrm{Na}_{2} \mathrm{~S}_{2} \mathrm{O}_{3}$ $\times 8000$ / Volume $(\mathrm{ml})$ of water sample

Where DO = Dissolved Oxygen; $\mathrm{V}=$ volume of water sample used for titration

$\mathrm{v}=$ volume of sodium trioxosulphate (II) (titrant); $\mathrm{N}=$ Normality of titrant

$8000=$ Constant since $1 \mathrm{ml}$ of $0.025 \mathrm{~N}$ sodium trioxosulphate (II) solution $=0.2 \mathrm{mg}$ oxygen (Dubey and Maheshwari, 2004).

Biological Oxygen Demand at day $5\left(\mathrm{BOD}_{5}\right)$

One $\mathrm{N}$ acid/ $1 \mathrm{~N}$ alkali was added to each water sample to adjust the $\mathrm{pH}$ to 7 . The sample was then transferred into BOD bottles gently so that bubbles did not come out. One $\mathrm{ml}$ of allylthiourea was added to each bottle to avoid nitrification. Dissolved oxygen was then measured using the steps described for dissolved oxygen. The other BOD bottle was incubated at $27^{\circ} \mathrm{C}$ for 5 days in a BOD incubator. The amount of oxygen was measured as done earlier

$\mathrm{BOD}_{5}(\mathrm{mg} / \mathrm{l})=\mathrm{D}_{1}-\mathrm{D}_{2}$

Where BOD = Biological Oxygen Demand; $\mathrm{D}_{1}=$ initial dissolved oxygen $(\mathrm{mg} / \mathrm{l})$ in the first halved sample $(\mathrm{mg} / \mathrm{l})$; $\mathrm{D}_{2}=$ dissolved oxygen $(\mathrm{mg} / \mathrm{l})$ in the second halved sample after 5 days of incubation (Dubey and Maheshwari, 2004).

\section{Sanitary surveillance}

i. The nature of the surrounding community and the level of development surrounding each well i.e. student area, market layout, agricultural layout or others.

ii. The adequacy of the well structure i.e. whether or not it is well protected, casted to its depths

iii. The hygienic conditions obtainable around the wells i.e. presence of a dump site, distance from toilets, septic tanks etc.

\section{Microbial analysis of water quality}

Enumeration of total coliform bacteria

Total bacterial count was done using the standard plate count methods for the examination using $10^{-4}$ dilution factor as described by Fawole and Oso (2001) and incubated at $37^{\circ} \mathrm{C}$ for $24 \mathrm{~h}$. The plates were observed for growth after $24 \mathrm{~h}$ and the number of discrete colonies on 
58

plates were observed and recorded in $\mathrm{cfu} / \mathrm{ml}$. TCBS was used for the detection of the presence of Vibro sp., by inoculating a $24 \mathrm{~h}$ old sample culture grown in peptone water (Mohammadi-Aragh, 2016).

\section{Enumeration offaecal coliform bacteria}

One hundred $\mathrm{ml}$ of the sample was filtered using a sterile Millipore apparatus and the filter membrane was aseptically transferred unto sterile EMB plate which was incubated at $44.5^{\circ} \mathrm{C}$ for $48 \mathrm{~h}$. The plates were observed for growth after $48 \mathrm{~h}$ and the numbers of discrete colonies on plates were observed and recorded in cfu/ml (Fawole and Oso, 2001).

\section{Enumeration of biofilm cell formation units (CFU)}

The method described by Huang et al. (2009) was adopted with few modifications. Organisms present in the water source were impacted on membrane filter and made to develop a biofilm community. The setup was made up of perforated weighted bottles, perforated Petri dish, Whatman filter paper with minimal organic matter content and high durability measuring $7 \mathrm{~cm}$ in diameter and a string was used. The apparatus was disinfected using ethanol and sterilized under UV-light 3 days before it was sunk in the well to a depth of at least one feet below the water surface. For each well under investigation four filter membranes were sunk, a pair for each periodic sample was retrieved on the $3^{\text {rd }}$ and $10^{\text {th }}$ day after the apparatus was immersed.

Upon withdrawal, the filter membranes were aseptically transferred into glass flasks containing $50 \mathrm{ml}$ sterile distilled water using sterile forceps. The flasks were mounted on a shaker device for thirty minutes to allow for re-suspension of the organisms in solution successively diluted to $10^{-3}$ after which $1 \mathrm{ml}$ of each of the suspension was drawn and plated unto freshly prepared MacConkey agar, Eosin methylene blue agar, Salmonella-Shigella agar, Pseudomonas Selective Agar, Thiosulfate Citrate Bile Salts Sucrose and Nutrient agar and incubated appropriately for 24-48 hours after which grown colonies were counted (Beściak and SurmaczGórska, 2011).

\section{Molecular analysis}

An overnight culture of the bacterium was prepared in nutrient broth. The cells were harvested by centrifugation and subjected to DNA extraction following the method of Dingle et al. (2005). The extracted genomic DNA was processed for PCR reaction using a cocktail mix $(10 \mu \mathrm{L})$ containing $(\mu \mathrm{L})$ : $10 \times$ PCR buffer $(1.0), 25 \mathrm{mM} \mathrm{MgCl} 2$ (1.0), 5 pMol forward primer (0.5), 5 pMol reverse primer (0.5), DMSO (1.0), 2.5 Mm DNTPs (0.8), Taq 5U/ $\mu \mathrm{l}$ (0.1), $10 \mathrm{ng} / \mu \mathrm{l}$ DNA (2.0) and $\mathrm{H}_{2} \mathrm{O}$ (3.1). The primers used were 16SF: GTGCCAGCAGCCGCGCTAA and 16SR: AGACCCGGGAACGTATTCAC. The PCR conditions were as follow: initial denaturation was done at $94^{\circ} \mathrm{C}$ for $5 \mathrm{~min}$, then 36 cycles of denaturation $\left(94^{\circ} \mathrm{C}, 30\right.$ s), annealing $\left(56^{\circ} \mathrm{C}, 30 \mathrm{~s}\right)$, and extension $\left(72^{\circ} \mathrm{C}, 45 \mathrm{~s}\right)$. Final extension was done at $72{ }^{\circ} \mathrm{C}$ for $7 \mathrm{~min}$ and holding temperature was $10{ }^{\circ} \mathrm{C}$. The amplicon (about $850 \mathrm{bp}$ ) was confirmed on $1.5 \%$ agarose gel using a $1 \mathrm{~kb}$ ladder (Invitrogen). The amplicon was purified by sequential washing with absolute ethanol and 70\% ethanol.
Sequencing was done at the International Institute for Tropical Agriculture (IITA), Ibadan, Nigeria. Sequence comparison was done using the BLASTN tool on the National Centre for Biotechnology Information (NCBI) website (www.ncbi.Nlm.nih.gov:80/BLASTN/).

\section{Results}

Physicochemical characteristics

pH of water sample

The $\mathrm{pH}$ of the samples ranged from $6.65 \pm 0.15-7.85 \pm$ 0.05 . well 1 sample 2 had the highest $\mathrm{pH}$ of $7.85 \pm 0.05$ while well 4 sample 1 the lowest value of $6.65 \pm 0.15$ (Fig. 1).

\section{Turbidity of water samples}

The lowest values were recorded in samples 3 well 3 and sample 5 well $6(1 \pm 0.00)$ while the highest was recorded in sample 3 well $7(23.5 \pm 0.5)$ recorded in Nephelometric Turbidity Unit (NTU). This corresponded to the periods when there was rainfall (Fig. 2).

\section{Total dissolved solids of water sample}

The TDS was lowest in well 1 sample $3141.5 \pm 2.5$ while the highest was recorded in well 5 sample $51421.5 \pm$ 1.5 parts per million (ppm) (Fig. 3).

\section{Temperature}

Temperature values expressed in ${ }^{\circ} \mathrm{C}$ ranged from 27.75 $28.5^{\circ} \mathrm{C}$ throughout the sample, the highest value of $28.5^{\circ} \mathrm{C}$ was obtained in well 7 sample 1 and sample 4, while the lowest was found in well 1 sample 1 and well 5 sample 4 (Table 1).

\section{Conductivity of water samples}

The conductivity was measured in $\mathrm{ms} / \mathrm{cm}$ which ranged from $0.195 \pm 0.005-1.755 \pm 0.005$. The lowest value was found in the $3^{\text {rd }}$ sample of well 1 while the highest was found in the $3^{\text {rd }}$ sample of well 5. These values were obtained around the neutral pH for those samples (Fig. 4).

Dissolved oxygen

The dissolved oxygen (DO) in $\mathrm{mg} / \mathrm{L}$ values fluctuated with the amount of water present in the wells at the time of withdrawal. The lowest recorded was well 1 sample 5 (35 \pm 1.0) while the highest recorded was in well 3 sample 1 and well 5 sample 5 (85 \pm 1.0$)$ (Fig. 5).

\section{Biological oxygen demand at day 5}

The values of Biological oxygen demand at day 5 $\left(\mathrm{BOD}_{5}\right)$ were recorded in $\mathrm{mg} / \mathrm{L}$. The lowest values were recorded in wells 4 and 6 of sample $3(3 \pm 1.0)$ while the highest was in well 5 sample 2 (Fig. 6).

\section{Sanitary surveillance}

The age, facilities and nature of well structures obtainable at the different sites varied as well as their sanitary conditions (Table 2). 
Microbial quality of water samples

Total coliform counts

The mean of total coliform counts for water samples is shown in Table 3.

The lowest total coliform count of $1.8 \times 10^{4} \mathrm{cfu} / 100 \mathrm{ml}$ was recorded in well 5 Sample 2 while the highest counts of $1.53 \times 10^{6} \mathrm{cfu} / 100 \mathrm{ml}$ was recorded in well 3 Sample 2 .

\section{Total faecal coliform counts}

The mean of total faecal coliform counts is shown in Table 4. The lowest total faecal coliform count of $2.0 \times 10^{3}$ cfu/ml occurred in wells $1,2,5,6$ and 7, respectively while the highest count occurred in wells 6 and 7 of sample 1 collection (Table 5).

In biofilm cell forming unit, the lowest count of $1.7 \mathrm{x}$ $10^{4}$ occurred in well 1 of sample 2 at day 10 while the highest of $1.0 \times 10^{5}$ occurred in well 6 of sample 1 at day 3 .

A total of twenty isolates were found in the course of the research work. These isolates included Shigella sonnei,
Shigella dysenteriae, Micrococcus luteus, Bacillus sphaericus, Salmonella enteritidis, Proteus mirabilis strain IK-MB4518F, Bacillus licheniformis strain RH104, Bacillus subtilis, Erwinia spp., Proteus vulgaris, Yersina spp., Bacillus cereus, Staphylococcus aureus, Serratia marcescens, Pseudomonas aeruginosa strain GS1, Pseudomonas aeruginosa 218B, Staphylococcus epidermidis, Vibro spp., Escherichia coli and Bacilluspasteurii (Table 6).

\section{Molecular identification of isolates}

Four isolates identified by molecular method were Pseudomonas aeruginosa XXX which shows $91 \%$ similarity with strain GSI, Pseudomonas aeruginosa XXX which shows 94\% similarity with strain 218B, Proteus mirabilis XXX which shows $95 \%$ similarity with strain IK-MB4-518F and Bacillus licheniformis which shows $94 \%$ similarity with strain RH104 using 16S ribosomal RNA gene, partial sequence deposited with Genebank.

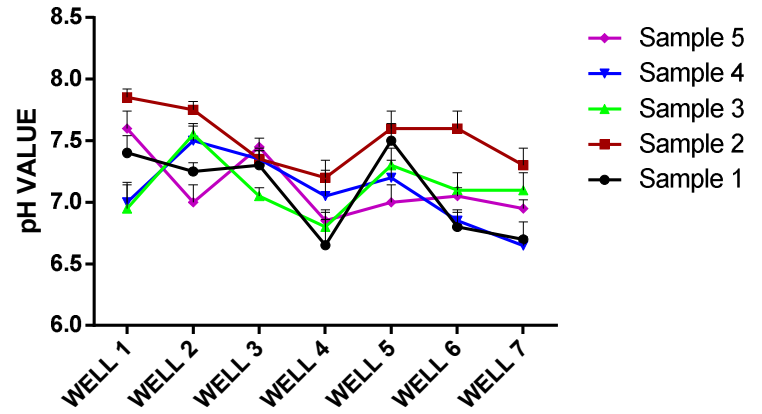

Fig. 1. $\mathrm{pH}$ of water samples

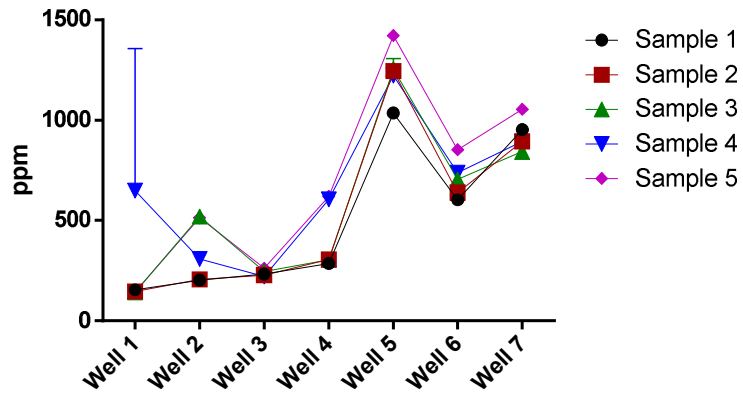

Fig. 3. Total dissolved solid

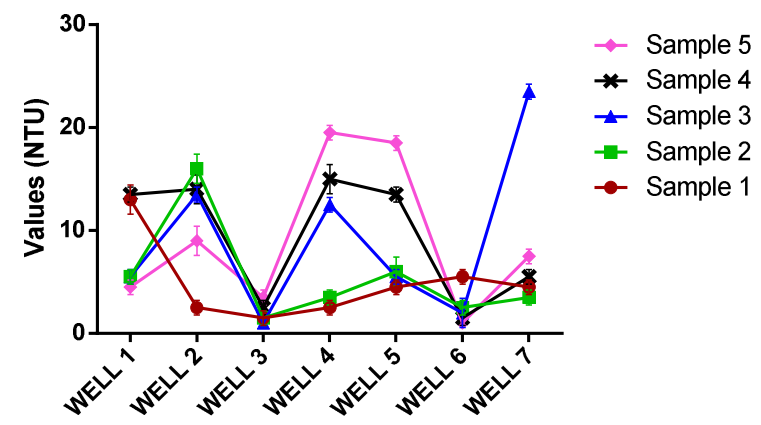

Fig. 2. Turbidity of water samples

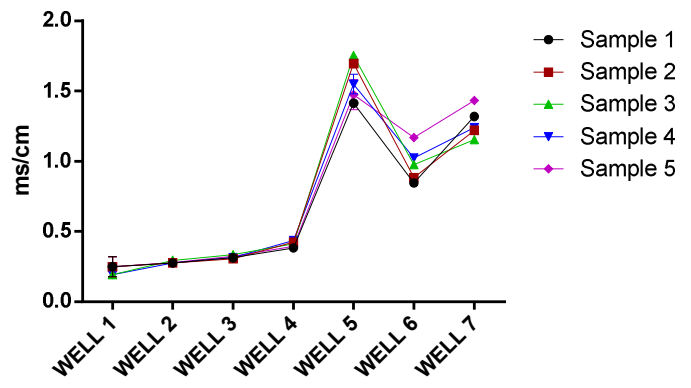

Fig. 4. Conductivity of water samples

Table 1. Temperature of water samples

\begin{tabular}{ccccc}
\hline SITE & Sample 1 $(\mathrm{C})$ & Sample 2 $(\mathrm{C})$ & Sample 3 $(\mathrm{C})$ & Sample 4(C) \\
\hline WELL 1 & $27.75 \pm 0.25$ & $28.3 \pm 0.19$ & $27.95 \pm 0.05$ & $28 \pm 0$ \\
WELL 2 & $28.05 \pm 0.05$ & $28.05 \pm 0.05$ & $28.05 \pm 0.05$ & $27.8 \pm 0.3$ \\
WELL 3 & $27.8 \pm 0.30$ & $28.1 \pm 0$ & $27.8 \pm 0.30$ & $27.5 \pm 0$ \\
WELL 4 & $28.05 \pm 0.05$ & $28.05 \pm 0.05$ & $28.05 \pm 0.05$ & $28.05 \pm 0.05$ \\
WELL 5 & $28.05 \pm 0.05$ & $28 \pm 0$ & $28.1 \pm 0$ & $27.75 \pm 0.25$ \\
WELL 6 & $28.25 \pm 0.25$ & $28.25 \pm 0.25$ & $28 \pm 0$ & $28 \pm 0$ \\
WELL7 & $28.5 \pm 0$ & $28.25 \pm 0.25$ & $28.25 \pm 0.25$ & $27.85 \pm 0.05$ \\
\hline Values represents means \pm Standard error of means. & & & $27.8 \pm 0$ \\
\end{tabular}


60

\section{Discussion}

The abundance of microorganisms in the water samples may be attributed to but not limited to the faulty or inadequate structures of these tube-wells, nearness to sources of contamination which included dump site and toilet facilities which are potential sources of leachate into the underground water, unhygienic practices and activities around the wells, indiscriminate use and poor handling of fetchers used for the wells and poor maintenance of the wells.

The $\mathrm{pH}$ of water samples recorded in the course of this research work varied between 6.65-7.85 for all the samples having an average of 7.2. This was in agreement with those obtained by Ogbonna et al. (2012), Agbabiaka and Oyeyiola (2012) as well as Ahaneku and Adeoye (2014), and it falls within the recommended range of 6.5-8.5, which is indicative for good water quality (UNEP/GEMS, 2007), advantageous for adequate water treatment and disinfection with chlorine (UNICEF, 2008), and for prevention of corrosion (WHO, 2010).

The turbidity of the water samples measured ranged between 1-23.5 NTU, these values were lesser than those obtained in surface waters as seen in the work done by Agbabiaka and Oyeyiola (2012). Only well 6 remained within the standard range of 5.0 NTU (WHO, 1984), which must have been possible because the well was cleaned out and re-casted during the course of the research work. These values obtained seem to have a relationship with the TDS along the sampling periods.

Total dissolved solids values ranged between 141.5 $1421 \mathrm{ppm}$. This result is lower to that obtained by Agbabiaka and Oyeyiola (2012) who worked on surface water.

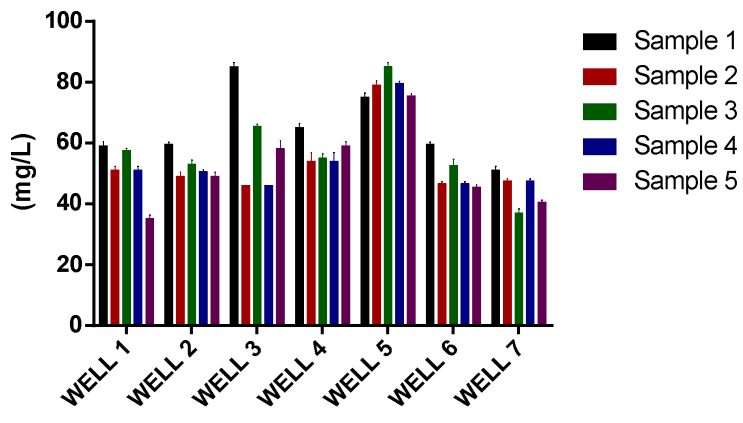

Fig. 5. Dissolved oxygen

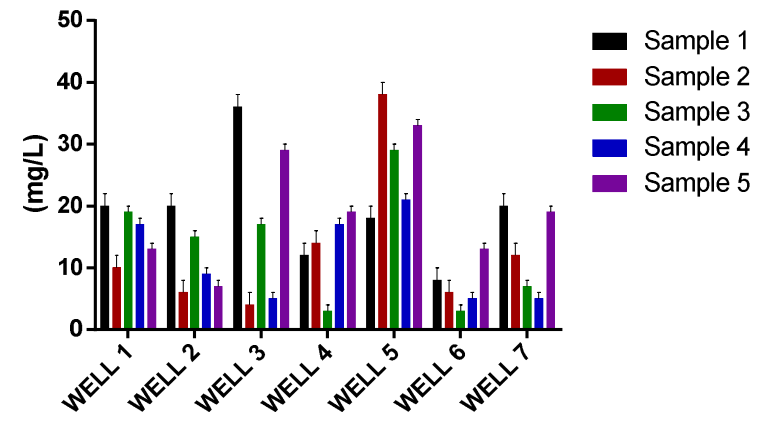

Fig. 6. $\mathrm{BOD}_{5}$

Table 2. Report on sanitary surveillance

\begin{tabular}{|c|c|c|}
\hline WELL & LOCATION & HYGIENIC DESCRIPTION \\
\hline WELL1 & $\begin{array}{l}\text { Tanke Bubu community, off } \\
\text { University of Ilorin road, Ilorin } \\
\text { Kwara state. }\end{array}$ & $\begin{array}{l}\text { The well has an adequate structure which includes a proper cover. The surrounding it neat and plastered. } \\
\text { However, it is sited beside a fish facility and adjacent to a neighbor's septic tank with maximum distance of } \\
\qquad 15 \mathrm{~m} \text {. the well is cleaned out every 2-3 years. }\end{array}$ \\
\hline WELL 2 & $\begin{array}{l}\text { Tanke Ajanaku community, off } \\
\text { University of Ilorin road, Ilorin } \\
\text { Kwara state. }\end{array}$ & $\begin{array}{l}\text { The well has an adequate structure which includes a proper cover, and a plastered neat environment. It is } \\
\text { not sited close to any visible source of contamination. It is cleaned out once in 2-3 years. }\end{array}$ \\
\hline WELL 3 & $\begin{array}{l}\text { Tanke Ajanaku community, off } \\
\text { University of Ilorin road, Ilorin } \\
\text { Kwara state. }\end{array}$ & $\begin{array}{l}\text { This well has a high water table year round, an adequate structure, a coverlid, as well as a neat and plastered } \\
\text { environment. It is however located close to one of the septic tanks in the compound. The well is accessed by } \\
48 \text { rooms in the compound and a lot of activities like washing, drying brushing etc. takes place around the } \\
\text { well. It is not cleaned out regularly because of its high water level. }\end{array}$ \\
\hline WELL 4 & $\begin{array}{l}\text { Tanke Bubu community, off } \\
\text { University of Ilorin road, Ilorin } \\
\text { Kwara state }\end{array}$ & $\begin{array}{l}\text { The structure of the well is not adequate, as it has a large mouth opening without a coverlid and the wall } \\
\text { cast has broken at its depths. For this reason it hasn't been cleaned out in a long time. The well is sited } \\
\text { downhill to a dump site, drainage system and close to a bathroom. }\end{array}$ \\
\hline WELL 5 & $\begin{array}{l}\text { Akerebiata community Off Sobi } \\
\text { road Ilorin. }\end{array}$ & $\begin{array}{l}\text { This well has a high water table year round, an adequate structure and a coverlid. It is however surround by } \\
\text { grasses and a farmland. It is rarely cleaned out. It is located about } 500 \mathrm{~m} \text { from gully erosion where wastes are } \\
\text { dumped and water flows through during the raining season. }\end{array}$ \\
\hline WELL 6 & $\begin{array}{l}\text { Off Adurlere road, adjacent to } \\
\text { Ore-Ofe hospital, Ipata } \\
\text { Community. Ilorin Kwara state. }\end{array}$ & $\begin{array}{l}\text { This well has a high water table year round, an adequate structure, as well as a neat and plastered } \\
\text { environment, however, the lid is broken. It is however located close to a place of worship where abolition is } \\
\text { done constantly. It is also close to an improper drainage system in the backyard of another building. It was } \\
\text { cleaned out in the course of this research work. }\end{array}$ \\
\hline WELL 7 & $\begin{array}{c}\text { Oja Oba Community, Ilorin } \\
\text { Kwara State. }\end{array}$ & $\begin{array}{l}\text { This well has an adequate structure, proper coverlid as well as a neat and plastered environment. It is } \\
\text { however located close to a place of worship where abolition is done constantly. It is not cleaned out } \\
\text { regularly because of its water depths and slippery nature of its wall. It is not sited close to any visible source } \\
\text { of contamination. }\end{array}$ \\
\hline
\end{tabular}


Table 3. Total coliform counts for water samples $\left(\mathrm{n} \times 10^{4} \mathrm{cfu} / \mathrm{ml}\right)$

\begin{tabular}{cccc}
\hline WELL & Sample 1 & Sample 2 & Sample 3 \\
\hline Well 1 & 5.2 & 2.8 & 4.9 \\
Well 2 & 6.5 & 3.7 & 3.7 \\
Well 3 & 5.8 & 153 & 3.1 \\
Well 4 & 107 & 4.0 & 55 \\
Well 5 & 7.4 & 1.8 & 3.4 \\
Well 6 & 6.5 & 2.3 & 3.8 \\
Well 7 & 120 & 3.3 & 4.8 \\
\hline
\end{tabular}

Table 4. Total faecal coliform counts for water samples $(\mathrm{n} \times 104 \mathrm{cfu} / \mathrm{ml})$

\begin{tabular}{cccc}
\hline WELL & Sample 1 & Sample 2 & Sample 3 \\
\hline Well 1 & 3.0 & 3.0 & 2.0 \\
Well 2 & 6.0 & 2.0 & 2.0 \\
Well 3 & 3.0 & 3.0 & 3.0 \\
Well 4 & 10.0 & 5.0 & 6.0 \\
Well 5 & 2.0 & 4.0 & 2.0 \\
Well 6 & 10.0 & 2.0 & 4.0 \\
Well 7 & 10.0 & 3.0 & 2.0 \\
\hline
\end{tabular}

It was also observed that this parameter increased along the periods of sampling. The highest values were found in well 5, a location that had agricultural activities going on in the area. Values were also seen to increase with rainfall period.

The temperature of the water samples varied from 27.5 $28.5^{\circ} \mathrm{C}$, the values were however similar to those of the work done by Ogbonna et al. (2012), Agbabiaka and Oyeyiola, (2012) and Oyem et al. (2014). This temperature range is favorable for adequate water quality maintenance as high temperature impacts negatively water quality by encouraging the proliferation of micro-organisms which impact taste, odour, colour of water and initiate corrosion problems in water distribution systems (UNICEF, 2008).

Table 6. Bacterial frequency distribution among sampling sites

\begin{tabular}{cc}
\hline Suspected Organism & \% Occurrence \\
\hline Shigella sonnei & 6.38 \\
\hline Micrococcus luteus & 2.13 \\
Bacillus sphaericus & 2.13 \\
Salmonella enteritidis & 2.13 \\
Proteus mirabilis strain IK-MB4-518F & 6.38 \\
\hline Bacillus licheniformis strain RH104 & 6.38 \\
Bacillus subtilis & 2.13 \\
Erwinia sp. & 2.13 \\
Proteus vulgaris & 4.26 \\
Yersina spp. & 2.13 \\
Bacillus cereus & 2.13 \\
Staphlococcus aureus & 8.51 \\
Serratia marcescens & 8.51 \\
Pseudomonas aeruginosa strain GSI & 10.64 \\
Shigella dysenteriae & 6.38 \\
\hline Peudomonas aeruginosa strain 218B & 2.13 \\
Staphlococcus epidermidis & 4.26 \\
Vibro spp. & 8.51 \\
Escherichia coli & 10.64 \\
Bacilluspasteurii & 2.13 \\
TOTAL & 100 \\
\hline
\end{tabular}

Table 5. Biofilm cell formation unit $\left(\mathrm{n} \times 10^{3} \mathrm{cfu} / \mathrm{ml}\right)$

\begin{tabular}{ccc}
\hline WELL & Sample 1 (Day 3) & Sample 2 (Day 10) \\
\hline Well 1 & 30 & 17 \\
Well 2 & 25 & 18 \\
Well 3 & 11 & 35 \\
Well 4 & 53 & 34 \\
Well 5 & 32 & 22 \\
Well 6 & 100 & 80 \\
Well 7 & 45 & 30 \\
\hline
\end{tabular}

Temperature affects solubility of gases such as $\mathrm{O}_{2}, \mathrm{CO}_{2}, \mathrm{~N}_{2}$ and $\mathrm{CH}_{4}$ (Yilmaz and Koç, 2014) which is important if the water is to be used for aquatic animals.

The electrical conductivity of the samples measured in $\mathrm{ms} / \mathrm{cm}$ ranged from $0.195-1.755$ similar to those obtained by Odeyemi et al. (2009). It is also within the permissible level of $1000 \mu \mathrm{S} / \mathrm{cm}$ as stated by NSDWQ (2007).

Dissolved oxygen (DO) recorded across all the samples ranged from $35-85 \mathrm{mg} / \mathrm{l}$ and was higher than those obtained by Adekunle et al. (2007). High DO is a good indicator of water quality that is able to support aquatic life, however, it can be ignored unless the water source was used for aquaculture as is the case in well 1 . This might have also been influenced by the low temperature range of the water samples as hot or warm water tend to contain less dissolved gases as obtained by Yilmaz and Koç (2014).

The Biological oxygen demand (BOD) of the water samples measured ranged from $3-38 \mathrm{mg} / \mathrm{l}$, similar but higher than those obtained by Adekunle et al. (2007) and Agbabiaka and Oyeyiola (2012). A high BOD value is a good indicator of polluted water (Shelton, 1991). The highest values were found to be repeatedly seen in both wells 3 and 5 which had a septic tank close by and surrounded by agricultural practice respectively.

The twenty bacteria isolated were similar to those obtained by Nwachukwu and Otokunefor (2006), Ekpo et al. (2010), Ogunnusi and Olanipekun (2010) Ajayi (2010) and Agbabiaka and Oyeyiola (2012) in their research works. Increase or decrease in bacterial populations can be attributed to the developmental stages of biofilm formation as described by Stoodley et al. (2000).

The presence of Bacillus spp. found in samples collected for both water quality and biofilms was in agreement to the work done by Nwachukwu and Otokunefor (2006) and Agbabiaka and Oyeyiola (2012), on water bodies that have soil bases. Heilard et al. (2000) and Rosef et al. (2001) also reported the presence of $E$. coli which was also obtained in this research work. Pseudomonas, Shigella, Salmonella and Vibro spp. found present in this study have been documented as health risks as stated by De-Victoria and Galvan (2001) and Taylor et al. (2000). 
62

\section{Conclusions}

The wells used in this study were found to contain bacteria in significant numbers, ranging from $1.8 \times 10^{4}$ to $1.53 \times 10^{6} \mathrm{cfu} / \mathrm{ml}$ values that are more than the permitted levels according to the drinking water standards. These wells in the light of this research can be said to pose serious health risks to its consumers.

In the light of this research findings, the populace in Ilorin Metropolis should be urged to boil water sourced from wells before use for domestic purposes to avoid attendant health risks while government at all levels should provide adequate potable water for the populace.

\section{References}

Adekunle IM, Adetunji MT, Gbadebo AM, Banjoko OB (2007). Assessment of ground water quality in a typical rural settlement in southwest Nigeria. International Journal of Environmental Research and Public Health 4(4):307-318.

Adeyemi O, Oloyede OB, Oladiji AT (2007). Physicochemical and microbial characteristics of leachate-contaminated groundwater. Asian Journal of Biochemistry 2(5):343-348.

Agbabiaka TO, Oyeyiola GP (2012). Microbial and physicochemical assessment of Foma River, Ita-Nmo, Ilorin, Nigeria: an important source of domestic water in Ilorin Metropolis. International Journal of Plant, Animal and Environmental Sciences 2(1):209-216.

Ahaneku IE, Adeoye PA (2014). Impact of pit latrines on groundwater quality of Fokoslum, Ibadan, South-Western Nigeria. British Journal of Applied Science and Technology 4(3):440.

Ajayi AO (2010). Microbiological study of surface and ground water sources in Akungba-Akoko, Ondo state, Nigeria. Book of Abstract (NSM FUTO2010)pp3.

Beściak G, Surmacz-Górska J (2011). Biofilm as a basic life form of bacteria. Proceedings of a Polish-Swedish-Ukranian Seminar, Krakow.

Dessie T (2014). An evaluation of hygienic barriers at Oset water treatment plant at different operational modes. Master's thesis, Norwegian University of Life Sciences, Ås).

DeVictoria J, Galvan M(2001).Pseudomonas as an indicator of health risk in water for human consumption. Water Science and Technology 43(12):49-52

Dubey RC, Maheshwari DK (2004). Practical Microbiology. S. Chad \& Company, New Delhi, pp 162-301.

Efuntoye MO, Bakare AA, Sowunmi AA (2011). Virulence factors and antibiotic resistance in Staphylococcus aureus and Clostridium perfringens from landfill leachate. African Journal of Microbiology Research 5(23):3994-3997.

Ekpo MA, Nyandou YMC, Ating M, Anele CC (2010). Distribution of pathogenic bacteria in freshwater fishes (Chrysichthys negrodigitatus and Synodontis robbianus) in Oku-Iboku river, Akwa Ibom state, Nigeria. Nigerian Journal of Microbiology 24(1):22142218.

Ersel M (2015). Water and sanitation standards in humanitarian action. Turkish Journal of Emergency Medicine 15:27-33.

Fatta D, Papadopoulos A, Loizidou M (1999). A study on the landfill leachate and its impact on the groundwater quality of the greater area. Environmental Geochemistry and Health 21(2):175-190.

Fawole MO, Oso BA (2001). Laboratory Manual of Microbiology. Spectrum Books, Ibadan, Nigeria, pp 15-45.
Flores-Tena FJ, Guerrero-Barrera AL, Avelar-González FJ, Ramírez-López EM, Martínez-Saldaña MC (2007). Pathogenic and opportunistic Gram-negative bacteria in soil, leachate and air in San Nicolás landfill at Aguascalientes, Mexico. Revista Latinoamericana de Microbiología 49(1-2):25-30.

Heilard ME, Sinclair MI, Fairley CK, Andrews RM, Bailey M, ... Kirk MD (2000). An outbreak of cryptosporiosis in an urban swimming pool: why are such outbreaks difficult to detect. Australian New Zealand Journal of Public Health 24(3):272-275.

Holt GH, KriegNR, Sneath PTA, StaleyJTF, William ST (2000). Bergey's manual of determinative bacteriology. Baltimore : Williams \& Wilkins (9 ${ }^{\text {th }}$ ed), Philadelphia.

Huang YL, Ki JS, Lee OO, Qian PY (2009). Evidence for the dynamics of Acyl homoserine lactone and AHL-producing bacteria during subtidal biofilm formation. The ISMEJournal3(3):296.

Mohammadi-Aragh MK (2016). Evaluation of urea hydrolysis as a biomarker for detecting pathogenic Vibrio parahaemolyticus in clinical isolates and raw oysters. $\mathrm{PhD}$ Thesis. MississippiState University.

Nwachukwu CI,Otokunefor TV(2006). Bacteriological quality of drinking water supplies in the University of Port Harcourt, Nigeria. Nigerian Journal of Microbiology 20(3):1383-1388.

Ogbonna CE, Njoku HO, Onyeagba RA, Nwaugo VO (2010). Effects of flooding and seepage from drilling burrow pit wastes on Orashi River, Egbema, Rivers State, Nigeria. Nigerian Journal of Microbiology 24(1):1993-2000.

Oshode OA, Bakare AA, Adeogun AO, Efuntoye MO, Sowunmi AA (2008). Ecotoxological assessment using Clarias gariepinus and microbial characterisation of leachate from municipal solid waste landfill. International Journal of Environmental Research 2(4):391400.

IM, Ezeweali D (2014). Temperature, pH, electrical conductivity, total dissolved solids and chemical oxygen demand of groundwater in BojiBojiAgbor/Owa area and immediate suburbs. Research Journal of Environmental Sciences 8(8):444-450.

Rosef O, Rettedal G, Lågeide L (2001). Thermophilic campylobacters in surface water: a potential risk of campylobacteriosis. International Journal of Environmental Health Resources 11(4):321-327.

Stoodley P, Sauer K, Davies DG, Costerton JW (2000). Biofilms as complex differentiated communities. Annual Reviews in Microbiology 56(1):187-209.

Taylor R, Sloan D, Cooper T, Morton B, Hunter I (2000). A waterborne outbreak of Salmonella saintpaul. Communicable Diseases Intelligence 24(11):336-339.

UNEP/GEMS (2007). Water quality outlook. United Nations Environmental Programme (UNEP)/Global Environmental MonitoringSystem(GEMS), Burlington, Ontario, Canada.

UNICEF (2008). Progress on drinking water and sanitation: special focus on sanitation. In Progress on drinking water and sanitation: special focus on sanitation. WHO/JMP.

WHO (1984). Guidelines for drinking water quality, drinking water quality control in small community supplies. WHO, Geneva, Switzerland 3:121-130

WHO (2010). Guideline for drinking water Quality. $3^{\text {rd }}$ Edition., World Health Organization, Geneva, Switzerland.

Yilmaz E, Koç C (2014). Physically and chemically evaluation for the water quality criteria in a farm on Akcay. Journal of Water Resource and Protection 6(02):63-67. 